\author{
${ }^{1}$ Li Moli Francesco, ${ }^{2}$ Mukhtarova Karlygash, ${ }^{3}$ Tovma N.A., \\ ${ }^{4}$ Kazbekova Kaurhan, ${ }^{5}$ Akimbaeva Karlygash \\ ${ }^{1}$ Associate professor Universita degli Studi di Parma (Italy) francasco@mail.ru \\ ${ }^{2}$ Doctor of economic sciences, professor, al-Farabi Kazakh national University, Almaty, Kazakhstan \\ e-mail: karlusha777mukhtarova@gmail.ru ORCID 55795620400 \\ ${ }^{3}$ Doctor $(\mathrm{PhD})$, associate professor al-Farabi Kazakh National University \\ nataliya-tovma@mail.ru, ORCID 56530735400 \\ ${ }^{4}$ C.e.s, associate professor al-Farabi Kazak National University, kazbekova kairzhan@mail.ru \\ ${ }^{5}$ Senior lecturer al-Farabi Kazak National University, karla74@inbox.ru, ORCID 57191362773
}

\title{
ANALYSIS OF THE CURRENT STATE AND DEVELOPMENT OF THE DIGITAL ECONOMY IN KAZAKHSTAN
}

\begin{abstract}
Annotation. The purpose of the study is to review and conduct a scientific analysis of the current state and development of the digital economy of the Republic of Kazakhstan, which determine the existing and prospective potentials.

Methodology-generalization, deductive approach, analytical comparisons, analysis and synthesis, statistical studies.

Originality/value-analyzed and systematized modern parameters of the state, causing the formation of sustainable development of the economy of the Republic of Kazakhstan, which allows you to specify the reserves and priorities of the quality of economic growth.

Conclusions - on the basis of the conducted research it is revealed that the current stage of the economy of the Republic of Kazakhstan requires a significant strengthening of the state policy to ensure its development, taking into account the trends of globalization of world economic policy, competition and scientific and technological progress. The analyzed quantitative and qualitative parameters of the economy showed that the main indicators of its growth do not correspond to the optimal level.
\end{abstract}

Key words - analyzed quantitative and qualitative parameters of the economy.

Introduction. Kazakhstan did not start "from scratch". In the $90 \mathrm{~s}$, the state program on forced industrial and innovative development was launched, the program of international education "Bolashak" was initiated, in 2005 the formation of "electronic government" was started.

The Foundation for the digital transformation of the economy of Kazakhstan was the state program "Information Kazakhstan-2020", approved in 2013. She contributed to the development of the transition to the information society, improvement of state management, establish institutions of "open and mobile government", increasing the availability of information infrastructure not only for corporate bodies but also for citizens. According to the results of three years of implementation of the state Program, it has already been achieved by $40 \%$.

In his Address, the Head of state noted that the development of the digital industry will provide impetus to all other industries. In this regard, the President set the task of developing new industries that are created with the use of digital technologies.
The main goal is the progressive development of the digital ecosystem to achieve sustainable economic growth, improve the competitiveness of the economy and the nation, improve the quality of life of the population.

The implementation of the state program is carried out in four key areas:

In the key world ranking of ICT development, calculated under the auspices of the UN - ICT Development Index, Kazakhstan in 2016 occupied the 52 nd place out of 175 , without changing its position since 2015. As a result of the Program and other strategic directions, the country will rise in the ranking to 30th place by 2022, 25th place by 2025 and 15 th place by 2050 .

According to the results of the report of the International telecommunication Union in the index of information and communication development in 2017, Kazakhstan ranks 52nd among 176 countries. In the CIS region, Kazakhstan is among the three leaders, placing on the 3rd place after Belarus (32nd place) and Russia (45th place). 
Literature review. Today, Kazakhstan has already created a number of elements of the innovation ecosystem, operates SEZ "PIT "Alatau", AOO "Nazarbayev University", launched the international Technopark Astana hub. 3/4 of the adult population of our country has a basic level of digital literacy, more than 3/4-have access to the Internet. This is a significant base from which we can build in the implementation of the Program.

In October 2017, at a meeting of the Supreme Eurasian economic Council, the heads of the EAEU member States approved the main directions of the digital agenda until 2025, and also supported the initiative of Nursultan Nazarbayev to hold a special meeting on the digitalization of the EAEU economy.

And such a meeting took place on February 2 this year in Almaty.

The last meeting of the EEU and the EAEU international forum "Digital agenda in the era of globalization" clearly confirmed the need to implement digital transformations in national economies within our common market and accelerated development of competitiveness on a global scale.

According to Ruslan Yensebayev, despite some differences in basic initiatives and approaches, the EAEU countries are actually at the starting point and understand the practical feasibility of synchronizing digital processes in the countries.

"I am sure that the EAEU has the capabilities, resources and competencies to compete with other States and integration associations for their place in the digital world," R. Yensebayev said.

Digitalization is significantly ahead of the existing system of production requirements for the composition of professions employed in the labor market.

The digital economy requires people to have the digital skills to benefit from it. At the same time, the current level of computer (digital) literacy of the population is $76.2 \%$, and its growth is needed in the coming years.

According to Ruslan Yensebayev, it is necessary to completely revise the content of all levels of education through the development of digital skills of all specialists.

For the development of technical and professional, higher and postgraduate education in order to bring together industry and education, measures are provided for the creation of ICT departments of Universities at enterprises, as well as competence centers.

1. Secondary education

At the moment, the Ministry of education and science of the Republic of Kazakhstan is already implementing a number of initiatives: 3-4 classes introduced the subject "Information and communication technologies", forming a common basic knowledge of working with modern information technologies for their effective use in education and everyday life. There are 372 robotics clubs that teach the General basics of programming within robotics.

The study of it competencies will be introduced in curricula at all levels of education, by $2025,100 \%$ of Kazakhstan schools is planned in elementary school to introduce the study of the fundamentals of programming, already in 2018 will increase the number of grants for the it profession and the opening of the it departments in major enterprises of the Industry 4.0.

2. Technical and professional, higher and postgraduate education

According to the MES on the basis of three specialties introduced the subject "Information and communication technologies", forming students " basic knowledge of the use of ICT in practice within the chosen profession.

Activities are also planned on updating educational programs based on professional standards and requirements of the labour market demand for new professions such as Data Science, Robotics, Genomics, Nanoelectronics and Nanomechanics, developers of high qualification for product development using technologies: Artificial Intelligence, Iot solutions, Blockchain, Additive technologies, BIM etc.

To date, training of ICT specialists for the sectors of the economy in Kazakhstan is conducted in 89 higher educational institutions in 11 specialties and in 318 organizations of technical and vocational education in 5 specialties.

From 2013 to 2017 ICT-occupations was released 109557 people, of whom 62964 people completed the training at the expense of budgetary funds.

At the same time, it should be noted that Kazakhstan has a specialized University that trains qualified ICT specialists for the sectors of the economy-the international University of information technology. There are also other strong universities, such as Suleiman Demirel University, KazakhBritish Technical University, Nazarbayev University, L. N. Gumilev Eurasian national University, etc.

3. The ecosystem of startups

An important and necessary condition, according to Ruslan Yensebayev, is the presence of technological entrepreneurs as a class, the development of a system of "orders" for technological projects, where customers are large local and international 
companies, and the performers are students. Since it is not possible to create a critical mass of Kazakh entrepreneurs in the short term, it is necessary to consider international experience.

"In General, countries with a developed ecosystem see foreign entrepreneurs and technology specialists as a source of specific know-how necessary for the development of a local startup ecosystem. Their experience, as well as technologies of research and development, entrepreneurship, management all the achievements that foreign experts are able to share, can help to accelerate the formation of a local ecosystem of startups. In addition, they provide a variety of cultures and knowledge, which in the future can become a competitive advantage for both the ecosystem itself and each of its participants", said the head of "Zerde".

The expert also notes that now much attention is paid to the development of the innovation ecosystem. For this purpose, Astana Hub was created on the basis of "Astana Expo", work is underway to select startups that will be accelerated on its basis.

This year it is planned to develop and bring to the level of ready-made companies 33 startups. Until 2022 - about 300 companies. Three R\&D laboratories (Research and Development) will also be opened with partners of Zerde holding, large international it companies.

In addition, this year it is planned to teach about 400 thousand businessmen and ordinary citizens the necessary it competencies (Belousov 2013:47).

The basis of digitalization of the economy is production. The concept of digital production is a set of tools to optimize the workflow through software and hardware solutions.

To put it quite simply, digitalization is nothing but a transition from analog to digital. This process involves not only the replacement of production tools, but also the introduction of analytical systems to maximize production cost-effective.

Material and Methods. Modern technologies can significantly reduce the cost and percentage of defects, while improving the quality of products, more and more companies will be motivated to use them - and over time, the digital economy will be perceived as quite a "traditional".

Briefly list the negative factors, which have to face, the foremost national mentality, fear, or even rejects all revolutionary new, throw in the laziness of the population and dependency expectations from the social subsidies of the state. The government agencies, officials and representatives of quasivector, unfortunately, still is bound to the commodity economy as the less risky and more profitable without excessive costs, and the majority of the business community, the principle of "buysell" prevails over innovation and the need for rapid and flexible changes.

This year, in his Address, the Head of state set clear objectives for the digitalization of all sectors, including industry, agriculture, transport, construction and housing, the financial sector, education and health care, public administration.

Minister of information and communications Dauren Abayev spoke about the plans for 2018, identifying the main areas in which it is necessary to do the work outlined in the plan and gave instructions to a number of key subordinate organizations.

Among the performance indicators planned for the current year, the main ones are:

At the same time, in 2018 the Ministry starts the project "Construction of fiber-optic communication lines in rural areas of Kazakhstan" the project will cover 1249 villages until 2020.

According to preliminary estimates, the direct effect of the digitalization of the economy of Kazakhstan by 2025 will create an added value of $1.7-2.2$ trillion. tenge, thus providing a return on investment in $4.8-6.4$ times by 2025 to the total volume of investments, taking into account private investment (Belousov 2013: 47).

The most significant effects in terms of GDP will fall on 12 key projects:

In addition to achieving economic impact and increasing competitiveness, digitalization will have a positive impact on the social sphere. By 2022, the effect of quality development of education, health care and the investment environment is expected to begin. This effect is insignificant on the horizon of the Program, but in the long term will significantly reduce the gap in socio-economic development with the top 30 developed countries of the world.

An important result of the Program will also be the acceleration of Kazakhstan's entry into the top 30 in the UN ICT development index.

"The key factors for the success of digital transformation in Kazakhstan can be a significant degree of involvement of the country's leadership, government agencies, and the government in the digitalization of all sectors of the national economy, through the systematic development of the ICT sector, creating a favorable environment for attracting digital innovation technologies, providing support to talented youth," Ruslan Yensebayev said (C John Pezzey, Michael A, 2002: 2-3)

Successful implementation of the impact of digitalization on the growth of production by 2022 will mean the following achievements: 
The widespread introduction of digital technologies will give impetus to the development of traditional basic industries by ensuring productivity growth and increasing their competitiveness, including in the international market.

Kazakhstan, implementing an integrated approach to digitalization, focused on such basic elements as digitalization of the mining industry and agriculture, further development of digital public services and ICT infrastructure. Special attention is paid to the development of human capital and the creation of an innovation ecosystem.

The digital economy has many advantages. Expected Digital dividends for Kazakhstan are defined and designated in accordance with the strategic objectives of the state.

As a result of the implementation of the state Program "Digital Kazakhstan»:

According to the Official website of the Prime Minister of Kazakhstan

How will Kazakhstan's economy turn into a digital one?

Since the beginning of this year, the strategically important state program "Digital Kazakhstan"has started. Let's see what is planned and what has already been done to prepare the economy of Kazakhstan for the fourth industrial revolution.

In the emerging digital economy group

According to the results of the study of the company "Boston consulting group" (BCG), reflected in the article "Kazakhstan on the way to the digital economy", the level of digitalization of the economy of Kazakhstan in 2016 ranked 50th place out of 85 countries and is in the group with the emerging digital economy. The digital divide between leading Nations and lagging Nations is widening year by year. The key to maintaining the competitiveness of Kazakhstan's economy is the development of the digital component through joint efforts of the state and business, including in such industries as industrial, transport and logistics, infrastructure, agriculture, subsoil use, energy, education and health care (Jackson, 2009: 1).

Therefore, this year launched an important state program for the development of modern Kazakhstan - "Digital Kazakhstan". It is designed for 20172020 and is of strategic importance for the country. The main goal of the program- " improving the quality of life and competitiveness of the economy of Kazakhstan through the progressive development of the digital ecosystem." It is no coincidence that the basis for its development was the decree Of the President of the Republic of Kazakhstan dated February 1, 2010 No. 922 "on the Strategic development plan of the Republic of Kazakhstan until 2020".

The Foundation of the program "Digital Kazakhstan "was the state program" Information Kazakhstan-2020", approved in 2013. According to the results of three years of implementation of "Information Kazakhstan-2020" it was achieved by $40 \%$. However, the rapid development of information technology on a global scale required an adequate and timely response from the government. Therefore, it was necessary to take the next step to initiate the process of transformation of the key sectors of the national economy, education, health care, as well as the sphere of interaction between the state and society and business.

According to the forecasts of the world's leading experts, by $2020,25 \%$ of the world economy will be digital, and the introduction of technologies to digitalize the economy, allowing the state, business and society to interact effectively, is becoming an increasingly large-scale and dynamic process. Expanding the role of information technology in the private and public sectors is the basis for the transition to the digital state. For these purposes, the state program "Digital Kazakhstan"was developed.

Price issue Initially in the draft state program "Digital Kazakhstan", which was published in 2016 JSC "national ICT holding "Zerde", the total cost of the program in $2017-2020$ was to be 384,220 billion tenge, including, in $2017-25,216$ billion KZT, in 2018 - 102,188 billion KZT, in 2019-94, 856 billion tenge, in $2020-161,958$ billion tenge. However, it was stipulated that the amount of funding from the national and local budgets will be specified in the formation of appropriate budgets for the planned period. As of may 2017, more recent figures appeared in the media. So, in 2017, on projects under the state program will spend 12 billion KZT, in 2018 - 57,3 billion KZT, in 2019 - 25,7 billion tenge, in 2020$\mathrm{m}-37,9$ billion tenge, finally, in 202117.8 billion tenge. As a result, it is planned to develop a budget of more than 150 billion tenge.

Who will pay? The source of expenditure will be the state budget and quasi-public sector funds, private investment, loans from financial institutions and development institutions. More specifically, about 140 projects will be implemented within the framework of "Digital Kazakhstan". And 44 projects will be implemented by the quasi-public sector. The bulk-69 projects will be financed from the state budget, 7 projects will be implemented through public-private partnership, 4 projects will be financed by international financial institutions, 9 projects will be financed from local budgets, 
and finally, 28 projects will be financed from the organizations ' own funds.

The effect of the investment of such large sums should become tangible results: Internet penetration in Kazakhstan - 81\%, productivity growth in ICT - at $43 \%$, the level of digital literacy is $81.5 \%$, the level of satisfaction with the quality of selfservices received in an electronic form $-84 \%$ share of volume of production and realization of goods (services) of the ICT sector in total GDP to $4.9 \%$.

The Ministry of information and communications of the Republic of Kazakhstan, which has developed the program, proposes to achieve these goals, acting in four key areas.

First, it is the creation of the "Digital silk road", which means the development of reliable, affordable, high-speed and secure digital infrastructure.

Secondly, the creation of a" creative society", which implies the development of competencies and skills for the digital economy, work to improve digital literacy of the population, training ICT specialists for industries.

Third, it is digital transformation in the sectors of the economy, the widespread introduction of digital technologies to improve the competitiveness of various sectors of the economy.

And fourthly, the formation of a" Proactive digital government", for which the system of electronic and mobile government will be improved, the scope of public services will be optimized.

Central and local government agencies are responsible for the implementation of the program.

What would we do? "Digital silk road" - the beginning

The implementation of the" Digital silk road " is closely connected with the development of modern cellular standards and the construction of backbone Internet networks. Fortunately, such initiatives are implemented by the market forces. Mobile operators are actively completing their 4G networks, and the standard was launched for the first time in Kazakhstan in December 2012 (in the cities of Astana and Almaty).

In addition, JSC "national infocommunication holding "Zerde" reminds that Kazakhstan already provides the shortest route for information flows between Europe and Asia, strengthening its competitive advantage in the market of international traffic transit. Acting as a coordinator of interregional initiatives, for example, the TASIM network project - TRANS-Eurasian high-speed information highway, Kazakhstan promotes the integration of data exchange centers of Western Europe and Asia. According to the analysis of the UN economic and social Commission for Asia and the Pacific ESCAP, Kazakhstan occupies a leading position in the capacity of international communication channels in the countries of the region.

At the same time, new realities dictate the need to constantly increase the capacity of ICT infrastructure, speed parameters of networks and achieve a high degree of security. Thus, according to Kaspersky Security Network, Kazakhstan has been the target of $85 \%$ of Internet attacks in Central Asia, compared with $8 \%$ in Uzbekistan, $4 \%$ in Kyrgyzstan, $2 \%$ in Turkmenistan and 1\% in Tajikistan.

The elimination of these threats is an excellent field for the efforts of the state. Ensuring confidentiality, integrity and availability of state information resources is a priori a basic task for the government of Kazakhstan. As practice shows, the reliability of the data center is achieved through the use of various backup schemes of engineering infrastructure at the design stage of the data center in accordance with international standards. At the same time, disaster resistance of both public and private data centers is ensured by reserving resources at a geographically remote site. Strengthening of information security measures within the framework of the program will be carried out by improving and further equipping testing and research laboratories of the State technical service, creating a system of accreditation of bodies confirming compliance with the requirements of information security standards. It is also necessary to improve information security at critical production facilities, in such industries as oil and gas, uranium, electricity, etc.

To avoid data loss of government information systems as a result of failure or temporary failure of the server center of government agencies, the program provides for the creation of a highly reliable and easily scalable data center of government agencies in accordance with international standards and information security (Jackson, 2009:1).

The study of international experience has shown that an effective means of combating various types of offenses with mobile network subscriber devices (cell phones) is blocking from connecting to cellular networks by IMEI-code of illegally used and imported phones. As a result, the blocked phone is not of interest to potential users, as it can not be used for its intended purpose.

This method is used in Azerbaijan, Turkey and other countries where there are Single data banks of IMEI-codes of phones with "white", "gray" and "black" lists (Krivonos U: 2016:3).

The solution to these problems is the creation in the Republic of Kazakhstan of a single database of 
identification codes of mobile network subscriber devices. The creation of a single database of identification codes of mobile network subscriber devices will block the connection to the networks of stolen, illegally imported into the country mobile devices, as a result of which the feasibility of economic smuggling and theft of phones will disappear.

\section{Developing the "creative society»}

In this area, the main task is to increase the level of computer literacy and training of ICT staff. Speaking with the report in may this year, Minister of information and communications Dauren Abayev first of all drew attention to the implementation of the state program "Information Kazakhstan". "The state program has fulfilled its purpose ahead of schedule, and the main target indicators planned for 2017 have already been achieved," the Minister said. - So, in the doing business rating of the world Bank, Kazakhstan took 35th place, and the share of the ICT sector in the country's GDP increased from $3.5 \%$ to $3.9 \%$. The level of computer literacy of the population exceeded 76\%."

According to him, in Kazakhstan more than $84 \%$ of households use the Internet, the number of subscribers of the national satellite network exceeded 1.2 million, $71 \%$ of the population turns to the domestic media for information. Every year in the field of ICT in Kazakhstan are on average 30 thousand people (submitted by the Committee on statistics of the Ministry of national economy of Kazakhstan: a University, 13 thousand persons, technical and vocational education -17 thousand people; according to the international scholarship "Bolashak" - 200 people).

At the same time, to this day there are a number of challenges, which are the need to increase productivity through training, improve the competitiveness of innovative domestic companies and new media platforms to increase the participation of citizens in the development of digital society. The world Bank's Digital dividends report also confirms that as new technologies evolve and penetrate new professions, workers will have to continually assess and improve their skills.

The program provides for bringing the level of education of graduates to the requirements of employers in the ICT industry. Acting as a bridge between the education system and employers, the program includes activities to support the education system, with the aim of creating real skills for new jobs in the economy.

During the implementation of the program, professional personnel in the field of education, medicine, production will be covered by teaching them practical digital skills. This approach will identify the need on the basis of new trends and involve relevant organizations that will provide the necessary assistance in specialized training. Since the demand for these skills is growing, an initiative will be created to develop such strategically important skills in key sectors of the economy by opening competence Centers on the basis of advanced universities in Kazakhstan.

With the aim of increasing digital literacy in the framework of the program will be developed a set of training materials and organized training to all segments of the population in all regions of Kazakhstan.

Create a "digital industry». In agriculture of Kazakhstan, the share of agricultural producers using digital technologies in the production of agricultural products is insignificant, which negatively affects the growth of yields and reduction of costs in agriculture.

According to "Zerde", for the further development of the agricultural sector in the framework of the program is planned: automation of the process of subsidizing agriculture, which would improve the transparency and efficiency of subsidies, as well as control over the development of allocated funds; the development of automation of registration, pledge, issuance of agricultural machinery, issuance of driver's licenses will allow to provide state services in the field of technical inspection for the population, to conduct centralized monitoring and control over the technical condition of agricultural machinery and compliance with legislation in the field of technical control and road safety; automation of traceability of livestock products, providing a full accounting of objects, identification of animals, tracking movements, including a system of response to diseases, which will allow industry representatives to quickly and effectively respond to various diseases when they occur; automation of traceability of crop products will track the entire life cycle of products, including the processes of production, storage, transportation, sale, destruction/disposal; automation of monitoring the turnover of fish and fish products will reduce the volume of poaching and illegal trafficking of fish products, as well as ensure the conservation of fish resources, collection and timely processing of information on the activities of fishing and fish processing organizations, enterprises engaged in the purchase and sale of fish and fish products, its wholesale and retail sale.

As the Foundation of the information and communication infrastructure of the subsoil use 
industry in Kazakhstan, within the framework of the state program "Digital Kazakhstan", it is planned to create a "national data Bank of mineral resources". The idea is that by providing a single tool for the collection and storage of data obtained from existing subsoil users, the state will not only ensure the safety of subsoil data, but will also be able to attract additional investment in the industry by providing these data to potential investors. In addition, this tool will increase the transparency of the state management of the mineral resource complex by automating the processes of granting subsoil use rights, excluding direct interaction of state bodies with the subjects of subsoil use rights.

Also for the digitalization of industry in Kazakhstan McKinsey\&Co in conjunction with the SEZ "Park of innovative technologies" (AlmatyTech Garden) plans to create a Centre of excellence for digital industry on the basis of the competence Center MMC together with the technological multinational companies, the purpose of which will be the pilot projects for mining enterprises for optimization and automation of production processes, conducting projects on the collection and in-depth analysis of the data.

First of all, information and communication infrastructure will be created, namely, measures will be taken to connect broadband access to the Internet, as well as industrial Internet for the implementation of digital industry projects at 10 large enterprises and 1 special economic zone.

In the future, it is planned to implement 10 projects for partial automation of production through the introduction and modernization of the sensor system.

It is planned to expand the use of digital technologies in transport and logistics by creating an Intelligent transport system. In Kazakhstan the introduction of its will allow to achieve the following objectives: to increase transit capacity through the management of the vehicle (routed as transit traffic, planning, movement of transit traffic, the observance of the established level of service, guaranteeing ontime transit flow, combining on-Board equipment necessary for the management of transit transport); strengthening transport security; logistics and transport management (ensures the management of passenger and cargo transportation, including the transportation of dangerous goods), improving the safety of regular passenger transportation by automating the functions of traffic control; accelerating the response and improving the efficiency of all transport services.

In addition, the project will develop e-Commerce, financial technologies, digitalized health care, education, will be built Smart-city.
Proactive government e-gov. According to the latest data from the UN and the world economic forum, Kazakhstan ranks 33rd in the e-government index and 39th in the network readiness index, leading among the CIS countries.

In the first half of 2017, eGov portal provided more than 18 million services to citizens. At the same time, the top five popular services provided through the e-government portal included the service "Issuance of information on the receipt and movement of funds of the depositor of the unified accumulative pension Fund". In the first half of this year, this service was used 1426237 times.

The greatest number of services rendered for the issuance address information from the place of residence - more than 10 million, in second and third place certificates on registered rights (encumbrances) to immovable property - more than 2 million and certificates on absence (presence) of real estate - more than 2 million, in fourth place - issuance information to the investor FUND. Completes the top services issuance of a certificate of the presence or absence of information about the Commission of a criminal offense-855 114 (Krivonos U: 2016:3).

It should also be noted that compared to the same period last year, the total amount of payments made through the eGov payment gateway increased by 1.4 billion tenge. In the first half of this year, this figure amounted to 7.7 billion tenge.

Analysis of the current state of the transport and communication complex of the Republic of Kazakhstan

The state and development of transport are of exceptional importance for the Republic of Kazakhstan.

Geographical features of Kazakhstan (vast territory, lack of access to the sea, uneven distribution of settlements and natural resources) make its economy one of the most cargo-intensive in the world, causing high dependence on the transport system.

Located at the crossroads of Europe and Asia, Kazakhstan has significant transit potential, providing Asian countries with geographically uncontested land transport links with Russia and Europe. The attractiveness of the transit potential of the Republic's airspace is also growing. The proximity to the States with huge markets makes the development of the domestic transport system promising.

Relatively flat landscape 7 and the presence of large reserves of natural stone allow unhindered development of rail and road transport.

The main share of the network of land routes is accounted for by roads and Railways (88.4 and 
14.0 thousand $\mathrm{km}$, respectively). The length of exploited waterways is 3.9 thousand $\mathrm{km}$, Airways - 61 thousand $\mathrm{km}$ density of the road network per 1000 square $\mathrm{km}$ is $5.1 \mathrm{~km}$ of Railways, 32.4 per $\mathrm{km}$ of roads paved, $1.5 \mathrm{~km}$ of inland waterways.

Kazakhstan's choice in favor of a market economy, made in the early $90 \mathrm{~s}$, and the reforms have significantly changed the working conditions of transport and the nature of demand for transport services.

In the first decade of transport reforms, basic structural and institutional changes were made. The legal basis of the transport industry has been created to meet the new socio-economic conditions. The functions of state administration and economic activity are divided, the system of state regulation of transport activity adequate to market conditions is created. Privatization of some modes of transport has mostly been completed.

The structure of organizational and legal forms and the number of transport enterprises in all sectors change annually. This indicates the continuing formation of an optimal market governed by the principles of competition and the real demand for transport services.

The system-forming role of transport has increased significantly and the interrelation of its development tasks with the priorities of socioeconomic transformations has improved. In General, transport met the growing demand for the transport of passengers and goods. From 2000 to 2005, the growth of transport services for the year was: passenger transport-7.8\%, freight transport-9.5\% (with an average annual economic growth of 10.3\%).

However, despite the General adaptation of transport to market conditions, the current state of the transport system cannot be considered optimal and its level of development sufficient.

The unbalanced location of the transport and communication network throughout the country hinders the development of the common economic space and the growth of population mobility. Industrial oriented network of Railways and roads were developed without regard to the territorial boundaries of the former Soviet республик8. Incompatibility of some technical parameters of transport infrastructure with international standards and systems of existing trade partners of Kazakhstan Is a significant obstacle to regional integration and development of trade and transport links.

Considerable unevenness in the development of the transport network hinders the economic development of the regions. About 2 thousand rural settlements do not have year-round transport links.
Security settlements regular message is 69.3 per cent.

At the present stage of its development, the transport complex of the Republic is characterized by an unsatisfactory state of fixed assets, outdated and underdeveloped infrastructure and technologies.

The share of transport costs in the cost of final products is relatively high and is at the level of $8 \%$ and $11 \%$, respectively, for domestic rail and road transport, in countries with developed market economies, this figure is $4-4.5 \%$. In terms of cargo capacity, Kazakhstan's economy is about 5 times less efficient. Thus, for each unit of GDP in dollar terms, there are at least 9 ton-kilometers of transport, and in the European Union, the cargo capacity is less than 1 ton-kilometer/dollar of GDP.

The growing demand for quality transport services is not fully met due to the insufficient level of technical development of the transport system and the lag in the field of transport technologies.

A significant increase in all transport volumes, including those related to the export of coal, oil cargo, metal products, chemical and petrochemical products, and other goods, is constrained by insufficient capacity.

The possibility of increasing the gross national product through the export of transport services is not fully realized, because the position of domestic carriers in the world market of transport services does not meet their real capabilities and the transit potential of the Republic is not fully used.

The location of the Republic of Kazakhstan in the center of the Eurasian continent predetermines its geopolitical role as a transit bridge between Europe and Asia, as well as between Russia and China.

On the territory of Kazakhstan are formed on the basis of the existing transport infrastructure in the Republic of four international transport corridors.

- The Northern corridor of the TRANS-Asian railway (TARM): Western Europe - China, Korean Peninsula and Japan via Russian and Kazakhstan (section Dostyk - Aktogai - Sayak - Mointy Astana

- Petropavlovsk (Presnogorkovskaya);

- Term southern corridor: South-Eastern Europe - China and South-East Asia through Turkey, Iran, Central Asian countries and Kazakhstan (section Dostyk - Aktogai - Almaty - Shu - Arys Saryagash);

- TRACECA: Eastern Europe-Central Asia via the Black sea, Caucasus and Caspian sea (on the Dostyk - Almaty - Aktau section);

- North-South: Northern Europe - Persian Gulf countries through Russia and Iran with participation 
of Kazakhstan at the sections: sea port Aktau - Ural regions of Russia and Aktau - Atyrau.

In addition to the areas participating in the formation of the main transcontinental routes, it is necessary to note the Central corridor term of importance for regional transit in the direction of Saryagash - Arys - Kandagach - Ozinki.

The corridors can significantly reduce the distance in the East-West communication and the delivery time of goods.

Results and Discussion. The strong growth of China's economy, in particular its Western regions, is already causing the need to deliver a variety of goods to world markets. However, according to experts, the level of development of transit in Kazakhstan does not correspond to the potential of the industry and the Republic as a whole. For example, in 2003, the volume of China's foreign trade with the EU countries amounted to 115 million tons, while the volume of transit traffic through the territory of the Republic of Kazakhstan in this direction amounted to about 3 million tons. The use of potential transit opportunities of corridors by major modes of transport is shown in table 1:

Table 1 - Potential transit opportunities of corridors by major modes of transport

\begin{tabular}{|c|c|c|c|}
\hline Mode of transport & Volume of transit in $\mathbf{2 0 0 5}$ & Potential opportunity & The use of the potential \\
\hline Railway, million tons & 8,895 & 30,0 & $30 \%$ \\
\hline Road, million tons & 0,350 & 3,0 & $12 \%$ \\
\hline Air, million aircraft-kilometers & 84,7 & 342,5 & $25 \%$ \\
\hline Sea, million tons & 0,150 & 2,5 & $6 \%$ \\
\hline
\end{tabular}

Geographically, the network of transport corridors is focused on meeting industrial and economic needs. It requires further optimization and partial reorientation, taking into account the prospects of territorial development, the placement of productive forces and the resettlement of the population.

Safety indicators of the transport process, primarily road traffic, do not correspond to the world level. Every year more than 3 thousand people die in road accidents (road accidents), which is more than 2 times higher than in developed countries.

Over the past 5 years, the annual increase in the number of victims in road accidents was about 10$15 \%$. If this trend continues, if the state does not take radical comprehensive measures to improve safety, including modernization of infrastructure, implementation of educational programs and strengthening of the law enforcement system, in 2015 the number of road accident victims may reach 10 thousand people.

The share of transport in environmental pollution reaches $30 \%$, which is more than 1.7 times higher than in developed countries.

Against the background of growing demand for transport services and its even more significant increase in the forecast perspective, a number of unresolved internal problems remain in the transport system as a whole and its individual sub-sectors.
The institutional and structural changes in the transport sector that have been initiated in recent years have not been properly developed. It is necessary to complete them consistently in order to create stable conditions for the further development of market relations in this sector of the economy.

The degree of depreciation and aging of fixed assets of the transport complex of Kazakhstan on average reached a critical level $-60 \%$, which led to a shortage of rolling stock and bringing the capacity of some sections to the limit.

The main railway network is not sufficiently developed. To optimize it, it is necessary to build new railway lines in the East-West direction.

As a result of long - term underfunding of railway transport, there was an accumulation of physical depreciation of fixed assets-more than $60 \%$. The industry uses technically and morally obsolete models of rolling stock, track equipment, worn track designs and uses outdated technologies for repair and maintenance of fixed assets. The efficiency of the operation system requires high costs to maintain fixed assets in working order.

Given the global trend of growth of cargo containerization ( $55 \%$ of total freight transport) requires development of container multimodal transportation and establishment of logistic 
centres, providing technological unity of different transportation types.

The network of roads of national importance is mainly formed. It is necessary to build roads in the latitudinal direction, linking Western Kazakhstan with the rest of the country. In addition, it is planned to build connecting sections on the roads with neighboring countries.

The unsatisfactory condition of the road surface leads to a decrease in operating speeds, an increase in operating transport costs, an increase in accident rate.

Depreciation of the rolling stock of the motor vehicle fleet (about $30 \%$ of buses and $40 \%$ of trucks have a service life of more than 13 years) leads to higher repair and operation costs, reduces the level of services and has a negative impact on the environment.

The network of international airports in Kazakhstan is optimal, but it is necessary to bring it in line with international standards. There are 21 airports operating in the Republic out of 22. Due to non-compliance with the technical standards of airfield complexes and due to the introduction of restrictions on the types of aircraft, only 5 airports (in Astana, Almaty, Aktobe, Atyrau and Karaganda) can accept heavy aircraft without restrictions. Other airports are in need of reconstruction.

The outdated fleet of aircraft (672 units), which are not economical and do not meet international standards for noise and engine emissions, creates restrictions in the service of international airlines. In this regard, it is important to create an attractive environment and the use of effective methods that contribute to the renewal of the aircraft fleet.

To a large extent, the development of air transport is affected by the lack of modernization of infrastructure and fixed assets of civil aviation. Due to insufficient capacity and non-compliance with technical standards, Kazakhstan's hub airports are forced to reduce the number of aircraft they receive and send, along with the introduction of restrictions on the types of aircraft.

Currently, in the Caspian region, Kazakhstan is represented by the only international commercial sea port of Aktau, which meets international standards of quality and technology of services provided. At the same time, the further development of the mining industry in the Western region of the country will bring the level of oil production to 140 million tons per year by 2015, which will lead to an increase in oil transportation through the seaport of Aktau in the amount of 20 million tons per year. This necessitates the expansion of the port's production capacity infrastructure to an appropriate level in the medium term, as well as the construction of oil terminals in other ports and the establishment of a support base for Maritime operations.

Most vessels of the inland water transport industry have developed 2-3 service lives. Depreciation of the state technical river fleet is $85 \%$.

Other significant problems of water transport are the technical condition and reliability of hydraulic structures (locks). Long service life (more than 50 years), mistakes made in the design and construction, increased seismicity of the area (6 - 7.5 points), aging of concrete structures, problems with the purchase of spare parts and equipment require urgent measures to carry out their reconstruction and modernization.

The level of import of technical means for the transport complex of Kazakhstan is high, it is more than $90 \%$ in certain industries. In this regard, it is necessary to form and develop domestic production for the repair and production of rolling stock, equipment and spare parts for the transport complex.

The level of funds allocated for the development of scientific potential in the transport industry is insufficient: according to expert estimates, it is less than $0.1 \%$ of transport revenues against $2-2.5 \%$ in developed countries.

The level of implementation of the fifth technological way (microelectronics, telecommunications, flexible automation, combined use of various structural materials) in the transport complex of the Republic is insufficient. For example, fiber-optic communication lines make up about $30 \%$ of the total length of the main communication lines of the Republic, in railway transport $-2.3 \%$.

The state of the infrastructure and fixed assets of the transport complex requires large investments from the state and the private sector. The rehabilitation of infrastructure and renewal of rolling stock through investment and the creation of favourable conditions for the development of a competitive market for operators are urgently needed.

There is a lack of complexity in the management of the development and functioning of the transport system, as well as in the coordination and interaction of different modes of transport.

Along with infrastructural problems, the transit flow through the territory of Kazakhstan faces a number of barriers, the most significant of which are unreasonable delays and procedural difficulties in passing customs and border control.

The activities of all sectors of the transport complex are characterized by inadequate regulation of transit tariffs. Natural monopolists providing transit transport services operate in conditions of 
fierce international competition, which requires greater flexibility in the formation of transit tariff policy.

The legislative base defining legal and organizational aspects of transport activity is generally formed. At the same time, in some industries there are no by-laws necessary for the implementation of the adopted sectoral laws. Existing regulatory and technical standards do not meet international standards and need to be harmonized. The legislation governing the transport sector should take into account the main provisions of international law in the field of transport. In order to improve the system of regulatory legal support for the functioning of transport, the development and adoption of a Transport code is being considered.

The current level of transport financing, which is about $1.5 \%$ of GDP, is much lower than in countries with similar territorial characteristics. Actively developing countries invest in the transport sector up to $4-7 \%$ of GDP.

Problems in the development of transport increase infrastructure constraints, reduce the level of social development and the formation of a single economic space. Their early resolution becomes particularly important in the context of the transition of the national economy into a phase of sustainable and qualitative growth.

Between 2000 and 2004, Kazakhstan's economy grew by 42.7 per cent in terms of GDP, and its production of goods and services grew by 41.9 per cent and 43.7 per cent, respectively. At the same time, the volume of cargo transportation by all modes of transport increased by $28.5 \%$. As a result, there is a situation when the existing capacity of the transport infrastructure constrains the growth of the economy.

The prospects of economic development of Kazakhstan with an expected saving GDP growth rate at $8.8-9.2 \%$ a year and bringing the annual average growth rate in the manufacturing industry to $8-8,4 \% 10$ will inevitably increase the burden on the transport system, particularly on the infrastructure of rail and road modes of transport, playing a key role in industrial and economic processes within the country and in its export-import and transit relations.

Raw material orientation of the state economy along with long distances at low population density causes a high dependence of the economy on transport. If during the economic downturn, the transport complex provided all the needs of the state's economy, as well as provided support by restraining tariffs and prices for transport services, now, in a period of stable economic growth, substantial state support is needed in the recovery and recovery of the transport industry.

Current state and development of digital economy in the Republic of Kazakhstan.

Conclusion. The relevance of the work is due to the modern development of the economy on the basis of digital technologies. Digital transformation represents the creation of innovative products and services based on a complex of advanced technologies, the formation of fundamentally new business models and business processes, advanced Analytics. This section is devoted to the problems of development of the digital economy in the Republic of Kazakhstan and adopted in different countries, one of the key indicators of digitalization of traditional industries.

The section discusses the current state and trend of development of the digital economy in the Republic of Kazakhstan. In the modern Republic of Kazakhstan there is a dynamic formation of the information society, the main components of which are: information and communication infrastructure; legal support; information tools and software and organizational and management system. The section discusses the observance of national interests, is also to create and implement a system of priorities for electronic technologies and services based on domestic developments. The program for the development of the national digital economy is also socially oriented and seeks to contribute to the creation of new opportunities for improving the lives of all social groups. In this regard, the national program for the development of the digital economy seeks to formulate development directions for the formation and maintenance of the most favorable organizational, infrastructural and regulatory characteristics of the Kazakh digital jurisdiction for business development in the new economic order, as well as the advanced development of national institutions of the digital economy.

Thanks. The article was written as part of the project AP05135078 Formation and development of the digital economy in the Republic of Kazakhstan: theory and practical measures of implementation

\section{References}

Analysis and forecast of parameters of transition to sustainable development [Electron. resource.] - URL: http://mybiblioteka. su/7-95695.html (date accessed: 11.2016) 
Belousov K. Yu. the current stage of evolution of the concept of sustainable development and shaping the corporate sustainability paradigm // problems of modern economy. - 2013. - № 1 (45). - p. 47-50.

Campbell McConnell, Stanley L. Brue, Sean M. Flynn Economics: principles, problems, and policies.20th ed. - NY: McGraw-Hill

Economic activity of the population of Kazakhstan / / statistical collection in Kazakh and Russian languages. - Astana, 2016. 214.

Environmental performance index [Electronic resource]. - URL: https://en.wikipedia.org/wiki/ Environmental Performance_Index (date accessed: 11.2016).

Industry of Kazakhstan and its regions / / statistical collection in Kazakh and Russian languages. - Astana, 2016. - $191 \mathrm{p}$

C. John Pezzey, Michael A. Toma The Economics of Sustainability: A Review of Journal Articles. - 2002. - Discussion Paper 02-03.

Jackson Prosperity Without Growth. Published by the Sustainable Development Commission. - March, 2009.

Kazakhstan ranks 63rd in the ranking of quality of life [Electron. resource.] - URL: http://365info.kz/2015/06/kazaxstan-zanimaet-63-mesto-v-rejtinge-po-kachestvu-zhizni/ (accessed: 16.09.2016)

Krivonos Yu. Economic theory. Lecture notes [Electron. resource.] - 2009. - URL: http://www.aup.ru/books/m240/3_7_4.htm (date accessed: 06.2016)

Population Of Kazakhstan [Electron. resource.] - URL: https://ru.wikipedia.org/wiki/Население_Казахстана (date accessed: 09.2016)

National accounts of the Republic of Kazakhstan / / statistical collection in Kazakh and Russian languages. - Astana, 2016. 103 p.

US Dollar exchange rate in Kazakhstan [Electron. resource.] - URL: http://kurstenge.kz/archive/usd (date accessed: 20.10.2016)

World economic forum: 2015 2015-2016 [electron. resource.] - URL: http://gtmarket.ru/news/2015/09/30/7246 (date accessed: 10.2016) 